\title{
VegMV - the vegetation database of Mecklenburg-Vorpommern
}

\author{
Florian Jansen, Jürgen Dengler \& Christian Berg
}

\begin{abstract}
We review VegMV, the phytosociological database of Mecklenburg-Vorpommern (NE Germany) with electronically stored vegetation relevés (GIVD ID EU-DE-001). The database was established in 1994 and is now hosted by the Institute of Botany and Landscape Ecology, University of Greifswald, Germany (http://www.botanik.uni-greifswald.de/VegMV). On 27 October 2011, the database contained 53,842 relevés, mostly from the federal state of Mecklenburg-Vorpommern, collected by approximately 320 authors between 1928 and 2010. Some $28 \%$ of the relevés were taken from published papers or monographs, $42 \%$ from theses and $30 \%$ from various unpublished reports and "field books". A wide variety of habitats occurring in Mecklenburg-Vorpommern are represented, but territorial coverage by relevés is uneven, with lower coverage of less attractive and poorly accessible areas. The largest numbers of relevés are from managed grasslands (Molinio-Arrhenatheretea), arable land (Stellarietea mediae), and eutrophic reed communities (Phragmito-Magno-Caricetea). We quantify and discuss possible bias in the data, such as preferential selection of sampling sites (habitat and small-scale preferences), taxonomic inconsistencies, spatial agglomeration, and missing values for some data elements. We present a brief introduction to the consistent phytosociological vegetation classification developed using the VegMV data. Further applications of the data and the conditions for their use are reported.
\end{abstract}

Keywords: biodiversity informatics; Germany; plant community; phytosociology; relevé; vegetation plot.

Nomenclature: Jansen \& Dengler (2008) for plants; Berg et al. (2004) for syntaxa.

Received: 17 December 2010 - Accepted: 26 May 2011 - Co-ordinating Editor: Jens Oldeland.

\section{Introduction}

Vegetation databases with species cooccurrence data have been compiled all over the globe (Dengler et al. 2011). It is estimated that in Europe alone nearly two million phytosociological relevés are stored electronically (Jansen et al. 2011b). This legacy of plot data spanning 100 years is a powerful resource for vegetation science (Ewald 2001, 2003, Dengler et al. 2011). New avenues of inquiry are now open for analysis, including phytosociological classification (Dengler et al. 2008), predictive mapping (Austin 2007), invasion ecology (Jansen et al. 2011b), functional traits (Cingolani et al. 2007), phylogeny (Cavender-Bares et al. 2009), assembly rules (Gotelli 2002) and biodiversity patterns (Ewald 2002, Lenoir et al. 2010). Such databases also offer many options for analysing patterns and processes of global change caused by anthropogenic climate warming, land-use changes and biotic invasions (Chytrý et al. 2009, Dengler et al. 2011).
VegMV, the vegetation database of Mecklenburg-Vorpommern (ID EU-DE001 in the Global Index of VegetationPlot Datases, GIVD, see Dengler et al. 2011) was established in 1990. It is a comprehensive database of published and unpublished vegetation-plot data from this federal state in NE Germany. With more than 50,000 relevés, it was for a long time the largest vegetation database in Germany, now being exceeded by the GVRD, GIVD-ID EU-DE-014 (see Jandt \& Bruelheide 2012). VegMV still is among the biggest worldwide (Dengler et al. 2011). While there have been two previous reports on the history and content of VegMV, in a book (Berg et al. 2004) and a regional journal (Berg \& Dengler 2004), we want to use this Special Volume dedicated to vegetation databases worldwide to give an updated overview of the data contained in VegMV, as well as their past and future uses. Specifically, we will describe the history of VegMV and report in detail on its content and representativeness, in this way updating the status report of Berg \& Dengler (2004). We will also describe how VegMV data have been used during recent years.

\section{History of VegMV}

The database project was initiated at a meeting of C.B. with Stephan Hennekens (Wageningen, The Netherlands) after the fall of the Iron Wall in 1990. At that time, TURBOVEG for DOS was emerging, and C.B. was one of the early users of this program. In 1992, the idea of a red book of plant communities of MecklenburgVorpommern arose and in the next two years a preliminary checklist of all recorded vegetation types was compiled based on community names used in the literature. In addition to published papers or books, a great amount of unpublished sources was included in the checklist (Berg 1993, Litterski et al. 1997). In order to build a comprehensive database of all available relevés, the state government sponsored several projects, served by a 
total of five employees between 1994 and 1998. In autumn 1997, a team of 22 scientists started to use these data for a de-novo classification of the vegetation in this region, which was completed four years later and has been published in Berg et al. (2001a). At that time, the database comprised about 50,000 relevés. It was converted to TURBOWIN (Hennekens \& Schaminée 2001), and plant nomenclature was largely standardised to Wisskirchen \& Haeupler (1998), Koperski et al. (2000), and Scholz (2000) for vascular plants, bryophytes, and lichens, respectively.

\section{VegMV}

Scope: All available vegetation plots within the area of Mecklenburg-Vorpommern (North-Eastern Germany) and neighbouring regions.

Status: completed and continuing

Period: 1922-2010

Database manager(s): Florian Jansen (jansen@uni-greifswald.de); Christian Berg (christian.berg@uni-graz.at); Jürgen Dengler

(dengler@botanik.uni-hamburg.de)

Owner: Landesarbeitsgemeinschaft Vegetationskunde

Web address: http://www.botanik.uni-greifswald.de/VegMV.html

Availability: according to a specific agreement

Database format(s): TURBOVEG

Online upload: no

Online search: no

Publication: [NA]

Plot type(s): normal plots

Non-overlapping plots: 53,842

Total plot observations: 53,842

Countries: DE: $100.0 \%$

Forest: $13 \%$ - Non-forest: aquatic: $9 \%$; semi-aquatic: $21 \%$; arctic-alpine: $0 \%$; natural: $3 \%$; semi-natural: $19 \%$; anthropogenic: $13 \%$

Guilds: all vascular plants: $100 \%$; bryophytes (terricolous or aquatic): $25 \%$; lichens (terricolous or aquatic): $10 \%$; algae (terricolous or aquatic):

$1 \%$; non-terricolous taxa (epiphytic, saxicolous, lignicolous): $1 \%$

Environmental data: altitude: $1 \%$; slope aspect: $10 \%$; slope inclination: $8 \%$; surface cover other than plants (open soil, litter, bare rock etc.): $4 \%$; soil $\mathrm{pH}: 1 \%$; land use categories: $1 \%$

Performance measure(s): presence/absence only: $1 \%$; cover: $99 \%$

Geographic localisation: GPS coordinates (precision $25 \mathrm{~m}$ or less): $8 \%$; point coordinates less precise than GPS, up to $1 \mathrm{~km}$ : $3 \%$; small grid (not coarser than $10 \mathrm{~km}): 80 \%$; political units or only on a coarser scale $(>10 \mathrm{~km}): 9 \%$

Sampling periods: $1920-1929: 0.1 \%$; 1930-1939: 0.9\%; 1940-1949: 0.0\%; 1950-1959: 3.3\%; 1960-1969: 14.1\%; 1970-1979: 13.1\%; 1980-1989: 12.0\%; 1990-1999: 53.2\%; 2000-2009: 2.0\%; 2010-2019: 0.0\%

Information as of 2012-07-18; further details and future updates available from http://www.givd.info/ID/EU-DE-001

Since 2001, improvements in database structure and taxonomy have been achieved. In addition to the original syntaxonomic classification, any relevé used in Berg et al. (2001a) was also assigned information from this later classification. Plant nomenclature was fully adapted to what was later published as GermanSL (Jansen \& Dengler 2008). Some 2,375 relevés from 40 new sources, such as theses, have been included. However, a considerable number of relevés within the area of Mecklenburg-Vorpommern have still not been included, or in some cases even digitized, these being mainly from forest inventories (see Schulze et al 2006).

\section{Basic statistical figures}

All figures presented in the following analysis reflect the status of the database on 1 November 2011. At this date, the database contained 53,842 relevés, of which nearly one half came from unpublished theses (Table 1), mainly from the Universities of Greifswald ( $n=12,106)$ and Rostock $(n=4,647)$. Nearly one third were from unpublished reports, for example surveys of nature reserves and management plans for specific areas. These surveys were commissioned by nature conservation agencies of MecklenburgVorpommern and conducted by different consultancies. Whereas the quality of the latter relevés varies considerably, none of these surveys was done for phytosociological classification purposes. Only $27 \%$ of the relevés in VegMV were from published papers or monographs; these dealt mostly with phytosociology or floristic questions. The majority of this group originates from the journals Natur und Naturschutz Mecklenburg (Vorpommern) $(n=2,964)$, Feddes Repertorium $(n=2,587)$, Archiv der Freunde der Naturgeschichte in Mecklenburg ( $n=$ 1,313), and Botanischer Rundbrief für Mecklenburg-Vorpommern $(n=1,147)$.

Table 1: Sources of the vegetation-plot data included in VegMV (as of 1 November 2011).

\begin{tabular}{lccc}
\hline & Number of sources & Number of relevés & Proportion of relevés \\
\hline Theses & 139 & 22,680 & $42 \%$ \\
Unpublished reports & 108 & 15,983 & $30 \%$ \\
Published papers and monographs & 381 & 14,828 & $27 \%$ \\
Unpublished relevés & 14 & 351 & $1 \%$ \\
\hline
\end{tabular}


The number of relevés per decade reflects the history of vegetation research in Mecklenburg-Vorpommern. There is an increasing amount of data since the beginning in the 1920 s but some political and scientific anomalies are apparent (Fig. 1). The oldest relevés are from 1928, recorded by Wilhelm Libbert (Libbert 1933). From the 1940s, there are only very few relevés, as a result of World War II. The high number of relevés in the 1960s was initiated by Prof. Franz Fukarek, who supervised many phytosociological theses in MecklenburgVorpommern. The extraordinarily high amount of relevés from the 1990s reflects the high number of surveys commissioned by public agencies after the fall of the Iron Wall, while the sharp drop in the number of new relevés after the year 2000 might partly be due to incomplete data coverage after the termination of the project.

\section{Data quality}

Sampling method and quality of relevés in phytosociological databases vary strongly for different reasons. Serious, but hardly avoidable, errors are introduced by overlooking or misidentifying species in the field (Vittoz \& Guisan 2007, Archaux 2009). In addition, different authors use different taxonomic concepts of species, subspecies or species aggregates. "Festuca ovina", for instance, is a frequent entry in the VegMV database but hardly any author specified whether they meant Festuca ovina s.str. or Festuca ovina agg. (both in the sense of GermanSL, i.e. Wisskirchen \& Haeupler 1998). Therefore, species or subspecies often need to be transformed to species sensu lato or aggregates in order to match taxonomic concepts in compiled datasets. Such transformations result in a loss of information, but are necessary in order to avoid bias in the analyses (Jansen \& Dengler 2010).

Another issue strongly related to data quality is the preferential selection of plot locations, which means that authors tend to select stands that fit their a priori idea of a particular vegetation type. This is to avoid "untypical" or "boring" stands and/or to try to sample a high betweenplot variance (Ewald 2003), which typically exceeds the variability caught by randomized sampling (Michalcová et al. 2011).

On a larger scale, preferential sampling leads to an unequal coverage of a given geographical region. The geographical distribution of relevés achieved during the entire history of phytosociological research in Mecklen-burg-Vorpommern is fairly good but still uneven (Fig. 2). The greatest gaps remain mostly to the east, in the sandy areas of the Uckermark and the southern part of the ground moraine. On the other hand, the coastal areas and Lake District, as well as the terminal moraines of the Weichselian Glaciation, are disproportionately well sampled. A particular focus has been areas with attractive vegetation (Darß, South-East-Rügen, Lake District) or with phytosociological "schools" in the vicinity (Güstrow, Rostock, Greifswald). An exception is the Elbe valley, which, despite being phytosociologically very diverse, appears undersampled (Fig. 2) because access was largely forbidden during the period of the German Democratic Republic.

It is an advantage of the VegMV database, compared to similar national and regional vegetation databases, that it includes to a large extent data from unpublished reports, for example environmental impact assessments. These studies often cover the "common landscape", which is neglected by phytosociologists for classification purposes. For this reason, the database includes many relevés of highly anthropogenic vegetation types and represents fairly well the dominant vegetation cover of Mecklenburg-Vorpommern. For example, the communities dominated by Calamagrostis epigejos and Rubus caesius, which are species-poor and considered "boring" but belong to the most frequent ruderal communities in central Europe, are represented by 219 and 57 relevés, respectively (in Berg et al. 2001, units 26.4.1.1 and 26.4.1.2). By contrast, they are completely missing in the recent database-driven classification of ruderal communities of the Czech Republic by Chytrý (2009).

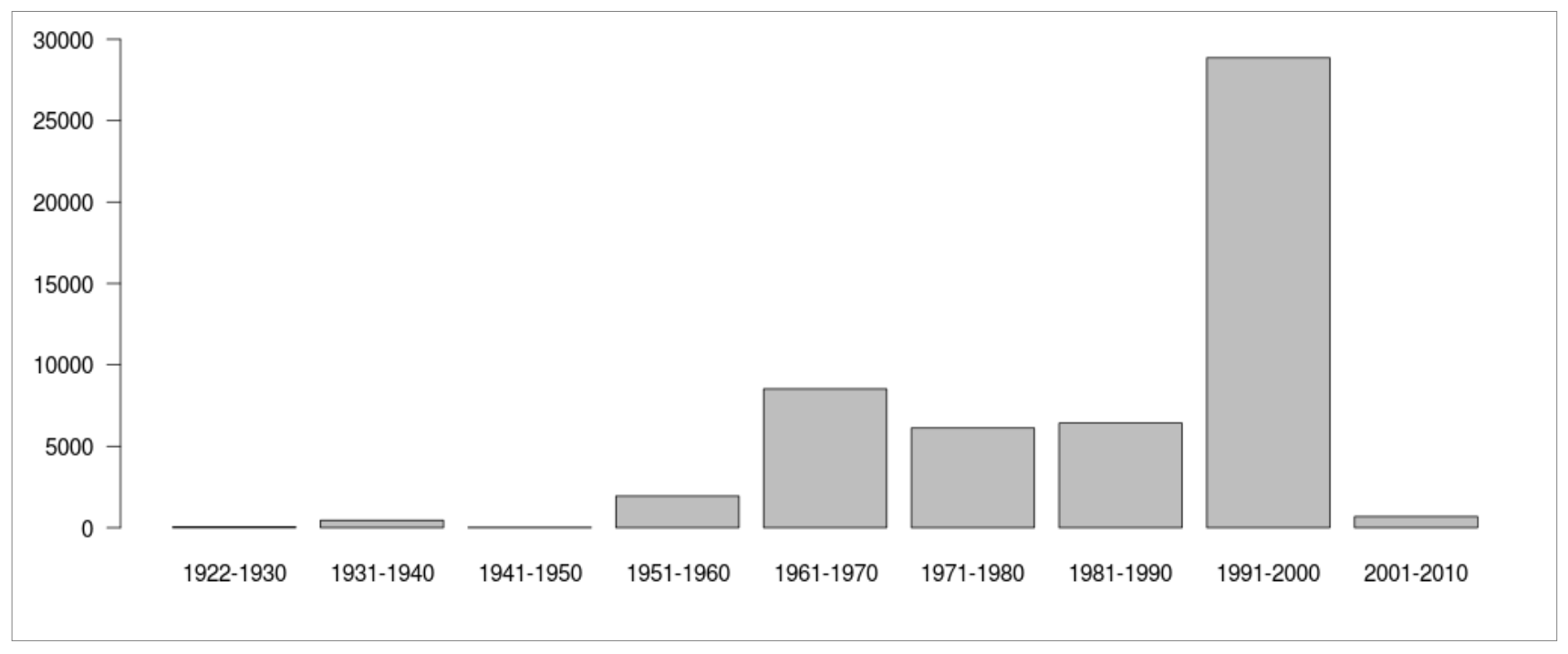

Fig. 1: Temporal pattern of vegetation plots included in VegMV (as of 1 November 2011). In cases where the actual date of record was unknown, the year of publication was used as surrogate. 


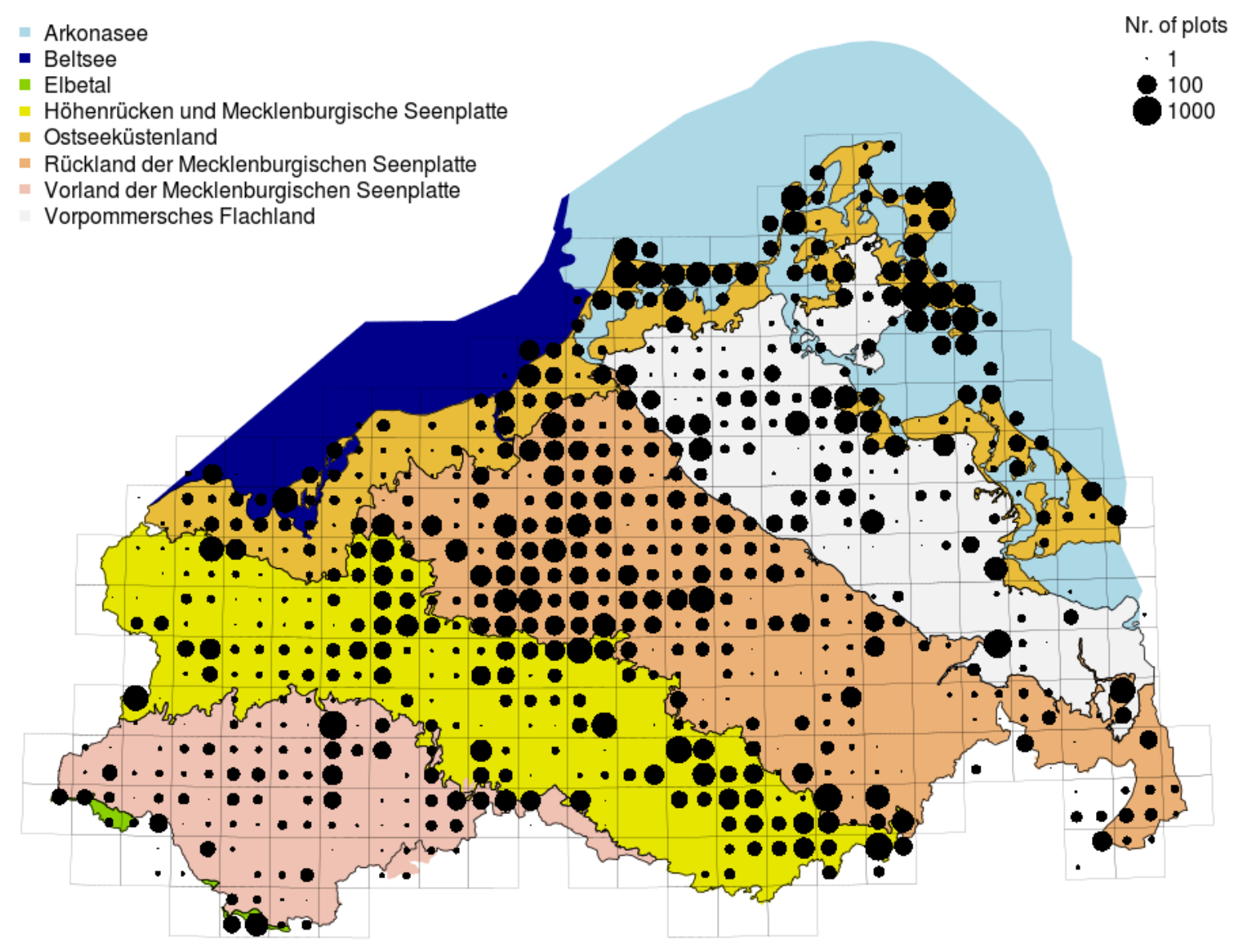

Fig. 2: Geographical distribution of vegetation plots stored in VegMV (as of 1 November 2011). The number of relevés is aggregated to quadrants of the Ordnance Survey 1:25,000 map series (Messtischblätter), each quadrant covering approximately $5.5 \mathrm{~km} \times 5.5 \mathrm{~km}$. The coastal region, Lake District and regions with terminal moraines are disproportional well sampled, while there are still gaps in SE Vorpommern and the southern part of the ground moraine, which is mostly used as arable land.

We also related the phytosociological classification from Berg et al. (2004) to the CORINE land cover data of Mecklenburg-Vorpommern (Bossard et al. 2000) to analyse the representativeness of the database in this respect (Table 2). Sea and lagoon regions are only represented by a few relevés despite their huge geographical extent (albeit only partially covered by vegetation). On the other hand, all terrestrial habitats except urban areas are more or less adequately represented (Fig. 3). However, the precision of this comparison is limited by the difficulty of matching the two classifications. The (semi-) automated classifications of CORINE 2000 cover have been accomplished on a scale of 1:100,000 and many vegetation types do not normally reach the threshold extent of approximately 25 ha to be considered by CORINE mapping. CORINE classes are somewhat inconsistent in classification criteria (Jansen \& Gregorio 2002) and often contain more than one phytosociological class. All groups in Figure 3 with a total cover below 5,000 ha could be influenced by a single large landscape patch assigned to this CORINE class. The best approach would be to look for the actual intersects between plot locations and CORINE patches, but the generally low georeferencing accuracy of vegetation plots within VegMV does not allow this.

A striking problem of VegMV (as practically all other vegetation databases, see Dengler et al. 2011) is the lack of plotbased structural and environmental variables. Mucina et al. (2000) attempted to standardise the sampling procedure by proposing obligatory and optional data elements associated with relevés. Of these "obligatory" data elements, the relevés in VegMV frequently lack field book number, total cover of all vegetation layers, height of vegetation layers, and for aquatic vegetation, the separate cover of emergent, natant, and submerged plants.

A verbal description of habitat characteristics is also frequently missing. The accuracy of the location varies from precise locations measured with a Global Positioning System (GPS) to the grid cells of the floristic mapping scheme (i.e. quadrants of the 1:25,000 Ordnance Survey maps, with a size of approximately $30 \mathrm{~km}^{2}$ each). Table 3 shows the percentages of missing values for obligatory data elements proposed by Mucina et al. (2000). 
Table 2: Assignment of phytosociological classes to CORINE level 3 landcover classes (CLC). This is the legend for Figure 3. The structural habitat types of the CORINE classification cannot always satisfactorily be matched with the phytosociological classification. Some classes that usually occur in small patches cannot be identified by the aerial survey with a resolution of 25 ha (marked with “*”). Others like CLC codes 243 and 322 are very heterogeneous in content (marked with "?”). The phytosociological forest types focus on environmental differences, not on dominant tree species. Therefore, the forest units in CORINE distinguished according to dominant trees could not directly be matched to phytosociological classes and vice versa, but only to an aggregated level that combines all forests(marked with “"**”).

\begin{tabular}{|c|c|c|c|}
\hline Code & Phytosociological name & CLC CODE & CORINE level 3 \\
\hline K01 & Lemnetea & 512 & Water bodies \\
\hline K02 & Zosteretea & 523 & Sea and ocean \\
\hline K03 & Ruppietea maritimae & 521 & Coastal lagoons \\
\hline K04 & Charetea & 512 & Water bodies \\
\hline K05 & Potamogetonetea & 512 & Water bodies \\
\hline K06 & Thero-Salicornietea strictae & 331 & Beaches, dunes, sands \\
\hline K07 & Isoeto-Nano-Juncetea & * & \\
\hline K08 & Bidentetea & * & \\
\hline K09 & Littorelletea & 512 & Water bodies \\
\hline K10 & Montio-Cardaminetea & * & \\
\hline K11 & Oxycocco-Sphagnetea & 412 & Peat bogs \\
\hline K12 & Parvo-Caricetea & 411 & Inland marshes \\
\hline K13 & Phragmito-Magno-Caricetea & $?$ & \\
\hline K14 & Juncetea maritimi & 331 & Beaches, dunes, sands \\
\hline K15 & Cakiletea maritimae & 331 & Beaches, dunes, sands \\
\hline K16 & Polygono-Poetea annuae & 112,121 & Discontinuous urban fabric; Industrial or commercial units \\
\hline K17 & Sisymbrietea & * & \\
\hline K18 & Stellarietea mediae & 211 & Non-irrigated arable land \\
\hline K19 & Asplenietea trichomanis & * & \\
\hline K20 & Calluno-Ulicetea & 322 & Moors and heathland \\
\hline K21 & Koelerio-Corynephoretea & 333 & Sparsely vegetated areas \\
\hline K22 & Festuco-Brometea & 231,321 & Natural grasslands \& Pastures \\
\hline K23 & Molinio-Arrhenatheretea & 231,321 & Natural grasslands \& Pastures \\
\hline K24 & Ammophiletea & 331 & Beaches, dunes, sands \\
\hline K25 & Trifolio-Geranietea sanguinei & 324 & Transitional woodland-shrub \\
\hline K26 & Artemisietea vulgaris & 112,121 & Discontinuous urban fabric; Industrial or commercial units \\
\hline K27 & Salicetea purpureae & 324 & Transitional woodland-shrub \\
\hline K28 & Vaccinio uliginosi-Pinetea & $311,312,313$ & Forest ** \\
\hline K29 & Molinio-Betuletea pubescentis & $311,312,313$ & Forest ** \\
\hline K30 & Alnetea glutinosae & $311,312,313$ & Forest ** \\
\hline K31 & Rhamno-Prunetea & 324 & Transitional woodland-shrub \\
\hline K32 & Vaccinio-Piceetea & $311,312,313$ & Forest ** \\
\hline K33 & Quercetea robori-petraeae & $311,312,313$ & Forest ** \\
\hline K34 & Carpino-Fagetea & $311,312,313$ & Forest ** \\
\hline
\end{tabular}

A comparison between the frequency of species within VegMV with (i) a random sampling of $100-\mathrm{m}^{2}$ plots in the adjacent federal states of Brandenburg and Lower Saxony (Dengler et al. unpublished, see Dengler \& Allers 2006) and (ii) the most frequent species within the Czech National Phytosociological Database (GIVD ID EU-CZ-001; Chytrý \& Rafajová 2003, see also Chytrý \& Michalcová 2012) reveals differences in natural conditions as well as methodology (Table 4). Wetland species such as Agrostis stolonifera, Phragmites australis, Galium palustre, Molinia caerulea or Cirsium oleraceum are indeed more frequent in the young moraine landscape of MecklenburgVorpommern with its many water bodies and fens compared to the two other survey areas. The total of 57 random plots from the neighbouring states were restricted to only two Ordnance Survey maps (No. 3049 in Brandenburg and No. 2728 in Lower Saxony) and might therefore not be representative of the whole area of these federal states. The proportion of forests is higher there than in Mecklenburg-Vorpommern, which might explain the higher frequency of, for instance, Impatiens parviflora and Quercus robur. A group of species that are very frequently recorded from random sam- pling, but which are not represented within the most frequent VegMV species, reveal a serious deficit in both vegetation databases: the very incomplete coverage of non-vascular plants in traditional phytosociological sampling. The most frequent species within the random samples of both adjacent federal states was Brachythecium rutabulum, a bryophyte with a broad ecological niche, which only had rank 87 in VegMV. In both vegetation databases, there was not a single bryophyte within the 40 most frequently recorded species. 
Table 3. The percentages of missing values of different variables in the relevés in VegMV. Percentages of missing cover values are calculated relative to the number of relevés that include a species from the particular layer.

\begin{tabular}{ll}
\hline Header field & Missing \\
\hline Year of sampling & $1.4 \%$ \\
Plot size & $29.0 \%$ \\
Altitude & $99.0 \%$ \\
Tree layer cover & $5.3 \%$ \\
Shrub layer cover & $5.0 \%$ \\
Herb layer cover & $57.6 \%$ \\
Moss layer cover & $2.4 \%$ \\
\hline
\end{tabular}

\section{Vegetation classification of Mecklenburg-Vorpommern}

The primary motivation for the establishment of VegMV was the consistent classification of the vegetation in MecklenburgVorpommern. At the outset of the vegeta- tion classification, three fundamental aims were formulated:

- It should be carried out in a uniform manner for all vegetation types according to logical and transparent principles.

- The vegetation units defined in this way should be applicable for both nature conservation practitioners and scientists.

- They should be compatible, as far as possible, with overviews of plant communities from neighbouring regions.

The resulting syntaxonomic system comprises 34 classes, subdivided into 12 subclasses, 70 orders, six suborders, 125 alliances, and 284 associations (Berg et al. 2001a, 2004). The classification was carried out separately for woodland vegetation ( 8 classes) and non-woodland vegetation (26 classes) as suggested by Bergmeier et al. (1990) and Dengler (2003). The frequency distribution of all species across the 34 classes was presented in an "all-class table", allowing for quick overviews and comparisons of the sociological preferences of each single species (Berg et al. 2001a). Character species of single classes, as well as joint differential species of two or three classes, have been identified (see Dengler et al. 2005), including bryophytes and lichens (see Berg \& Dengler 2005).

The established "joint differential species" for more than one class allow a connectivity network to be drawn between them (Fig. 4, see also Figs. 2 and 3 in Berg \& Dengler 2004). For the nonwoody vegetation, aquatic and saltinfluenced communities were the most separated types, whereas all communities dominated by perennial plants formed the body of the "elephant of phytosociology".

The nature conservation assessment was done by differentiating the vulnerability of plant communities conceptually from their nature conservation value (Berg et al. 2001b). The combination of both in a decision matrix led to a priority ranking of communities that most urgently need protection and management (Timmermann et al. 2006).

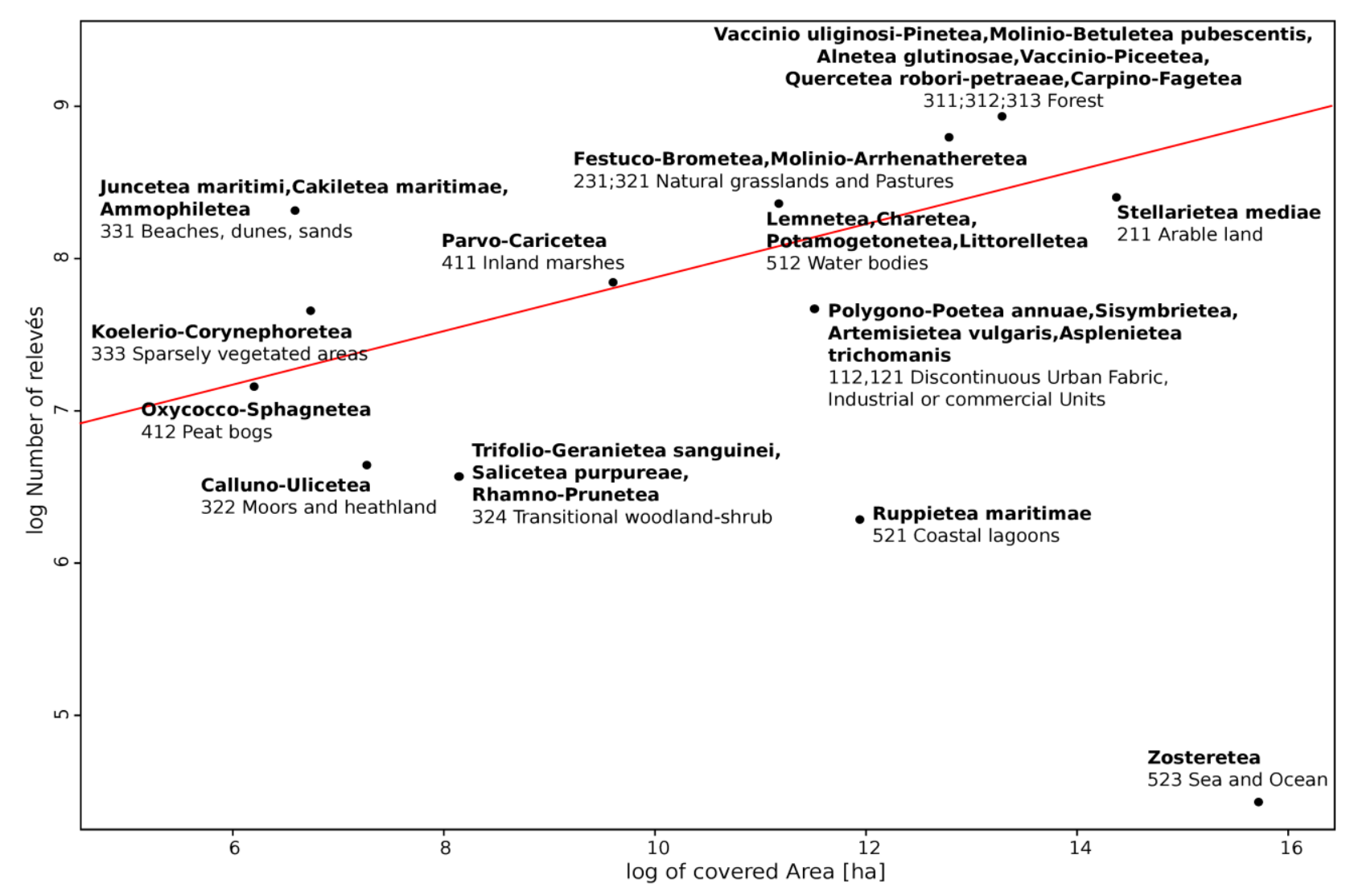

Fig. 3: Frequency of phytosociological classes compared to the land cover of CORINE level-3 classes in MecklenburgVorpommern in log-log representation. The classification system is given in Table 2. Whereas ocean and coastal lagoons are represented only by a small number of relevés despite their large spatial extent, most terrestrial ecosystems, including freshwater bodies, are more or less proportionally represented by relevés. Forests, grasslands, and coastal regions are over-sampled. The linear regression (red line) is calculated without sea, coastal and urban areas. 
Table 4: Most frequent species or species aggregates in the VegMV database, compared to the ranking of a random sampling of 100-m² plots in Brandenburg $(n=16)$ and Lower Saxony $(n=41)$ from Dengler et al. (unpublished, see Dengler \& Allers 2006), and a comparable ranking within the Czech National Phytosociological Database (Chytrý \& Rafajová 2003). Bryophytes are marked with "(B)". The 30 most frequent species of VegMV and the 15 most frequent species of the other surveys are shown (table sorting indicated in bold).

\begin{tabular}{|c|c|c|c|}
\hline Taxon & Rank VegMV & Rank BB + NI & Rank CZ \\
\hline Poa pratensis agg. & 1 & 25 & 2 \\
\hline Festuca rubra agg. & 2 & 17 & 6 \\
\hline Elymus repens & 3 & 3 & 29 \\
\hline Holcus lanatus & 4 & 25 & 31 \\
\hline Urtica dioica & 5 & 17 & 3 \\
\hline Agrostis stolonifera agg. & 7 & 216 & - \\
\hline Phragmites australis & 6 & 216 & - \\
\hline Deschampsia cespitosa & 8 & 216 & 5 \\
\hline Poa trivialis subsp. trivialis & 9 & 22 & 20 \\
\hline Taraxacum spec. & 10 & 6 & 4 \\
\hline Dactylis glomerata subsp. glomerata & 11 & 12 & 14 \\
\hline Achillea millefolium agg. & 12 & 40 & 1 \\
\hline Cirsium arvense & 13 & 46 & 33 \\
\hline Ranunculus repens & 14 & 216 & 7 \\
\hline Galium palustre & 15 & - & - \\
\hline Molinia caerulea & 16 & - & - \\
\hline Stellaria media & 17 & 6 & - \\
\hline Cerastium holosteoides & 18 & 17 & - \\
\hline Trifolium repens & 19 & 12 & 36 \\
\hline Plantago lanceolata & 20 & 25 & 9 \\
\hline Lysimachia vulgaris & 21 & 216 & - \\
\hline Galium aparine & 22 & 25 & 40 \\
\hline Rumex acetosa agg. & 23 & 216 & 11 \\
\hline Potentilla anserina & 24 & 216 & - \\
\hline Juncus effusus & 25 & 127 & - \\
\hline Ranunculus acris & 26 & 216 & 8 \\
\hline Lythrum salicaria & 27 & 127 & - \\
\hline Cirsium oleraceum & 28 & - & - \\
\hline Viola arvensis & 29 & 46 & - \\
\hline Agrostis capillaris & 30 & 6 & 25 \\
\hline Brachythecium rutabulum (B) & 87 & 1 & - \\
\hline Hypnum cupressiforme var. cupressiforme (B) & 100 & 2 & - \\
\hline Fagus sylvatica & 45 & 4 & 22 \\
\hline Lolium perenne & 76 & 4 & - \\
\hline Quercus robur & 40 & 9 & - \\
\hline Chenopodium album & 56 & 10 & - \\
\hline Lophocolea heterophylla (B) & 343 & 10 & - \\
\hline Impatiens parviflora & 291 & 12 & - \\
\hline Rubus corylifolius agg. & 1420 & 12 & - \\
\hline Scleropodium purum (B) & 261 & 12 & - \\
\hline Veronica chamaedrys & 117 & 91 & 10 \\
\hline Picea abies & 356 & 127 & 12 \\
\hline Oxalis acetosella & 66 & 22 & 13 \\
\hline Anthoxanthum odoratum & 37 & 486 & 15 \\
\hline
\end{tabular}




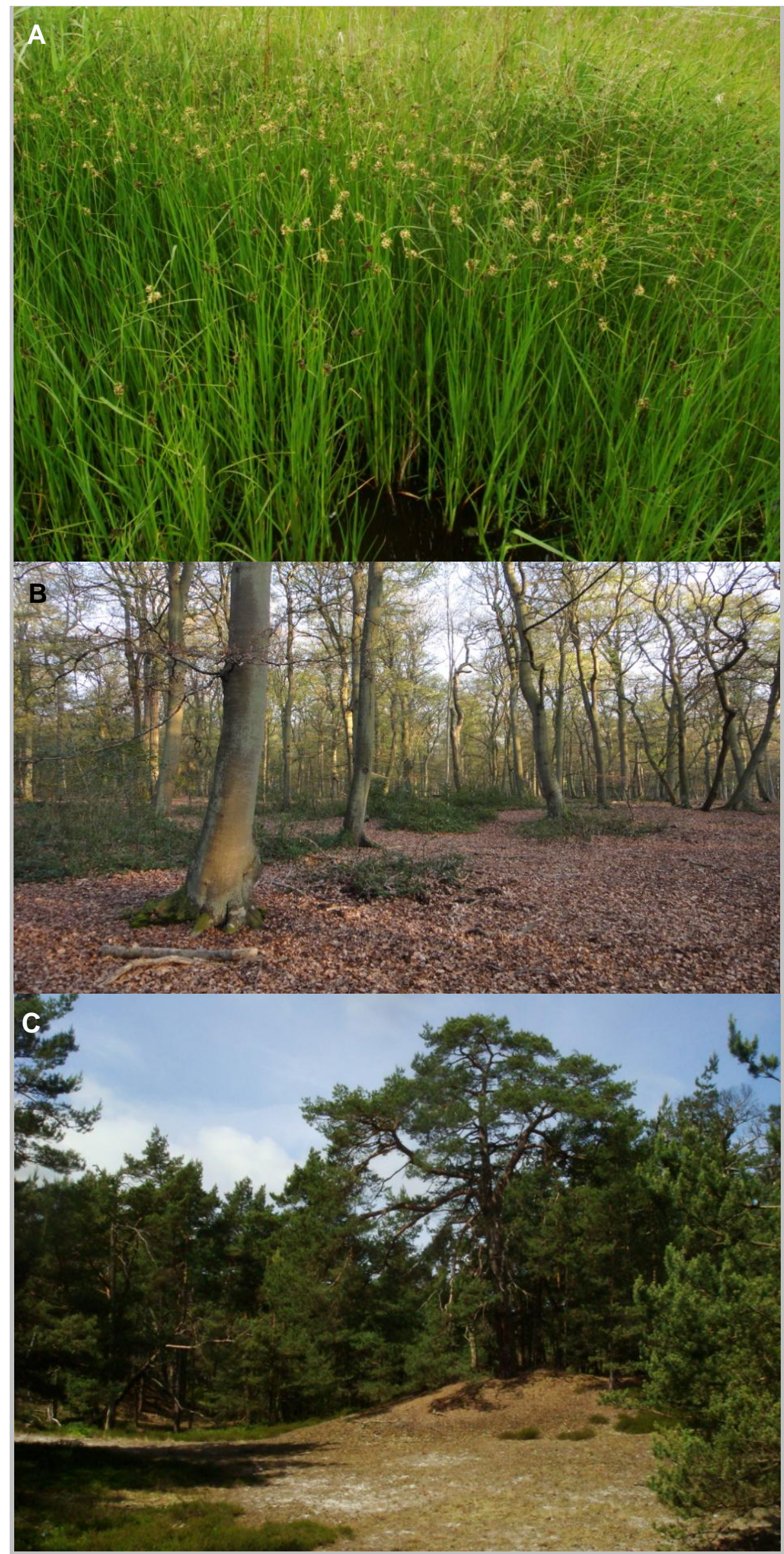

Plate: Vegetation types featured by the vegetation-plot database GIVD EU-DE-001.

A: Bolboschoenetum maritimi is the most common reed community of brackish waters in the coastal lagoons of MecklenburgVorpommern. While often dominated by Phragmites australis, Bolboschoenus maritimus is more dominant at higher salinity or surge of weaves. Neither facies can be separated as a separate association based on the relevés available in VegMV, despite their high number (Photo: C. Berg).

B: Early spring aspect of the Lonicero periclymeno-Fagetum, which reaches its eastern-most limit at the coastline of Mecklenburg-Vorpommern

(Rostocker Heide). Ilex aquifolium is procumbent because of wind and browsing (Photo: $\mathrm{C}$. Berg).

C: Vaccinio myrtilli-Pinetum sylvestris with Empetrum nigrum. Here, at the young coast of Darßer Ort, it is a near-natural community, but in terms of species combination it is similar to human-induced secondary forest stands (Photo: C. Berg). 


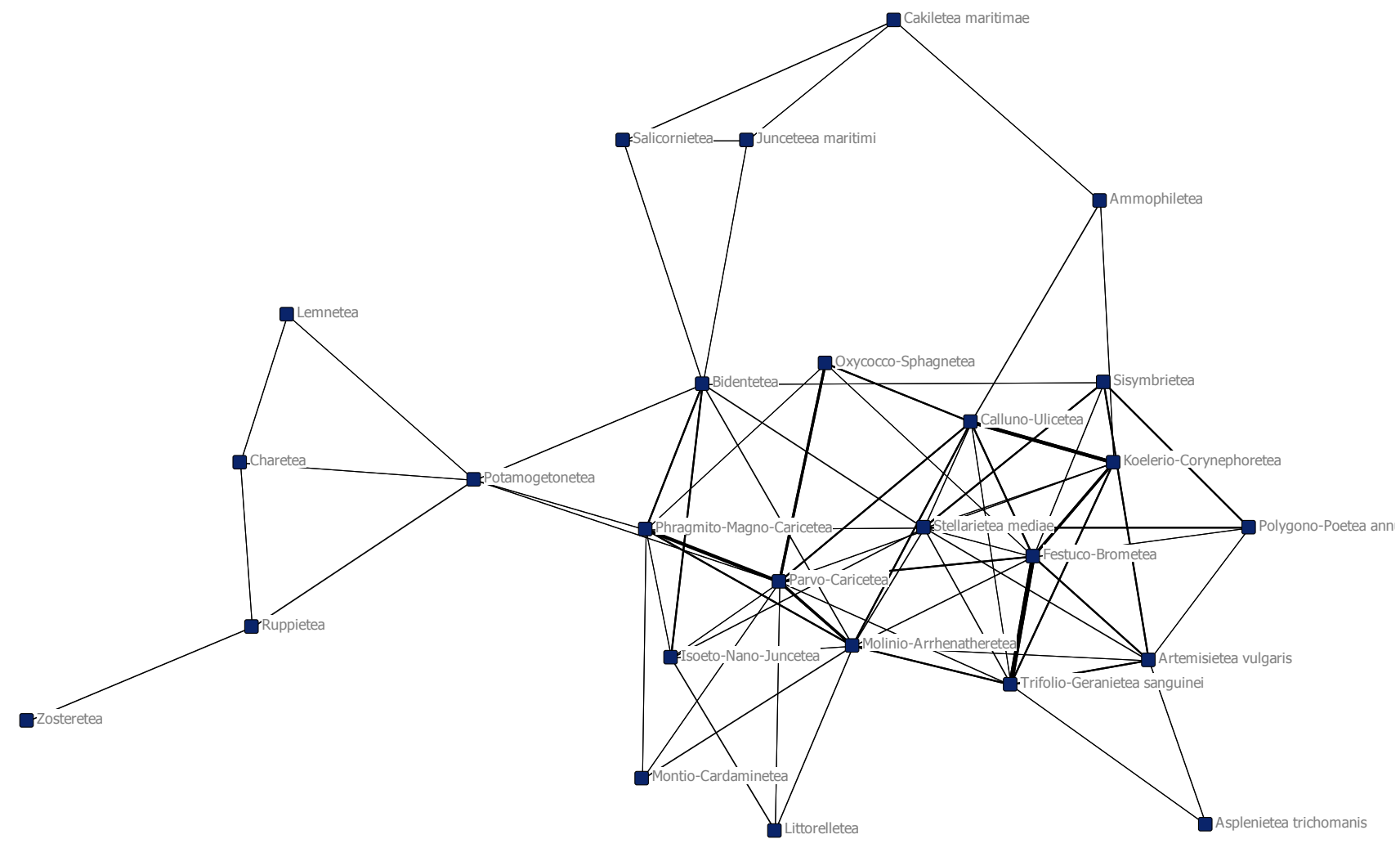

Fig. 4: Multivariate scaling of the distance matrix of joint differential species between herbaceous vegetation classes of Mecklenburg-Vorpommern (Berg et al 2004). Scaling was done with NetDraw version 2.048 (Borgatti 2005). The "head of the elephant" is built by the aquatic classes whereas the seat is built by communities of salty habitats. The terrestrial classes dominated by perennial species form the body of the elephant.

\section{Other applications of VegMV}

Right at the outset of the project, it was the intention to disseminate VegMV data for analyses beyond the primary goal of classification. All kinds of practical or theoretical research questions concerning the information encapsulated in the database are also welcome by external users (contact is F.J.).

A Letter of Agreement has been formulated, stating the following conditions:

1. Data are provided for free, but donations are welcome. If applicable, we will ask for non-monetary compensation like providing additional plotrelated data that are gathered by the users.

2. The data are extracted from the database without further inspection. We give no guarantee for data accuracy.

3. The recipient is bound to:

- use the data only for the announced purpose and only non-commercially;
- not give the data to a third party;

- accredit VegMV properly in all publications that use the data (from now on this shall be done by citing this Long Database Report and mentioning the GIVD ID EU-DE-001),

- cite the original sources if using single relevés explicitly and not only aggregated data; and

- provide to the database manager (F.J.) copies (e.g., as pdf files) of all publications that use the data.

Table 5 gives an overview of selected projects that requested VegMV data in the past. Data have been used in theses (e.g. for comparison with own survey data), but also for international publications in practical and theoretical vegetation science. The high number of relevés makes it possible to apply new methods. Even without measurements of environmental conditions, it was possible to calculate the ecological preferences of alien species along gradients estimated by ecological indicator values of plants (Jansen et al. 2011a). The unavoidable bias in sampling density has been outweighed by the huge number of relevés from all kinds of habitats. To account for the inherent nonindependence of species occurrences in vegetation relevés, Jansen et al. (2011a) permuted the ecological indicator values across all occurring species to calculate "non-confidence bars" for the ecological preferences at specific gradient segments.

Vegetation-plot databases focus on cooccurrence (Dengler et al. 2011) but provide also valuable floristic information. The average number of species per relevé in VegMV is 17, making up a total of 904,986 floristic field observations of individual plant taxa within time and space. These constitute more than one third of the total floristic survey available in the federal state (see http://www.floramv.de). 
Table 5: Overview of users and purposes for which VegMV data have been provided so far. Data are available according to a special agreement (for details, see text).

\begin{tabular}{|c|c|c|c|c|c|c|}
\hline Date & Inquirer & Institution & Aim & Topic & $\begin{array}{l}\text { \# of } \\
\text { relevés }\end{array}$ & Publication(s) \\
\hline $\begin{array}{l}\text { Jan } \\
2006\end{array}$ & Jürgen Dengler & Univ. Hamburg, DE & Publication & $\begin{array}{l}\text { Dry Grasslands - Festuco- } \\
\text { Brometea }\end{array}$ & $?$ & $\begin{array}{l}\text { Dengler et al. } \\
(2006)\end{array}$ \\
\hline $\begin{array}{l}\text { May } \\
2006\end{array}$ & Mirja Dörsing & Univ. Münster, DE & $\mathrm{PhD}$ & Corynephorion & 603 & - \\
\hline $\begin{array}{l}\text { Oct } \\
2006\end{array}$ & Tristan Lemke & Univ. Rostock, DE & $\mathrm{PhD}$ & $\begin{array}{l}\text { Population ecology of Trollius eu- } \\
\text { ropaeus }\end{array}$ & 3,055 & Lemke (2007) \\
\hline $\begin{array}{l}\text { Jan } \\
2007\end{array}$ & $\begin{array}{l}\text { Zuzana } \\
\text { Münzbergová }\end{array}$ & $\begin{array}{l}\text { Academy of Science, } \\
\text { Pruhonice, CZ }\end{array}$ & Publication & Population biology of rare species & 9,596 & - \\
\hline $\begin{array}{l}\text { Feb } \\
2007\end{array}$ & Maike Isermann & $\begin{array}{l}\text { University of Bremen, } \\
\text { DE }\end{array}$ & Publication & Plots with Rosa rugosa & 38 & Isermann (2008) \\
\hline $\begin{array}{l}\text { Jan } \\
2009\end{array}$ & Thilo Heinken & Univ. Potsdam, DE & Publication & Pinus forests & 456 & $\begin{array}{l}\text { Fischer et al. } \\
\text { (2009) }\end{array}$ \\
\hline $\begin{array}{l}\text { May } \\
2009\end{array}$ & Michal Hájek & Masaryk Univ., CZ & Publication & Caricion davallianae in Europe & 419 & - \\
\hline $\begin{array}{l}\text { May } \\
2010\end{array}$ & $\begin{array}{l}\text { Wieger Wa- } \\
\text { melink }\end{array}$ & Wageningen Univ., NL & Database & $\begin{array}{l}\text { Ecological Conditions Database } \\
\text { (EC) }\end{array}$ & 363 & - \\
\hline $\begin{array}{l}\text { Jun } \\
2009\end{array}$ & Klaus Kloss & $\begin{array}{l}\text { Mecklenburg- } \\
\text { Vorpommern, DE }\end{array}$ & Publication & $\begin{array}{l}\text { Salty vegetation of coastal areas } \\
\text { (Wismar-Bucht) }\end{array}$ & 157 & - \\
\hline $\begin{array}{l}\text { Mar } \\
2010\end{array}$ & Javier Loidi & $\begin{array}{l}\text { Univ. Basque Country, } \\
\text { Bilbao, ES }\end{array}$ & Publication & Senecion fluviatilis in Europe & 31 & - \\
\hline $\begin{array}{l}\text { Apr } \\
2010\end{array}$ & Florian Jansen & Greifswald Univ., DE & Publication & $\begin{array}{l}\text { Ecological preferences of alien } \\
\text { species }\end{array}$ & 53,000 & Jansen et al. (2011) \\
\hline $\begin{array}{l}\text { May } \\
2010\end{array}$ & Jonathan Lenoir & Aarhus Univ., DK & Publication & $\begin{array}{l}\text { Absolute and relative species } \\
\text { richness in different regions of } \\
\text { Europe }\end{array}$ & 10,000 & - \\
\hline $\begin{array}{l}\text { Jun } \\
2010\end{array}$ & $\begin{array}{l}\text { Stephan Hen- } \\
\text { nekens }\end{array}$ & Alterra, Wageningen, NL & Publication & Ecology of Fritillaria meleagris & 34 & - \\
\hline Jul 2010 & Maike Isermann & $\begin{array}{l}\text { University of Bremen, } \\
D E\end{array}$ & Publication & Eryngium maritimum & 101 & - \\
\hline $\begin{array}{l}\text { Oct } \\
2010\end{array}$ & Anna Liebaug & TU München, DE & $\mathrm{PhD}$ & $\begin{array}{l}\text { Meta-analysis of vegetation } \\
\text { relevés of } 20 \text { selected species }\end{array}$ & 7,961 & - \\
\hline $\begin{array}{l}\text { Apr } \\
2011\end{array}$ & Christian Berg & University of Graz, AT & Publication & Ricciocarpos natans & 128 & $\begin{array}{l}\text { Gosch \& Berg } \\
(2011)\end{array}$ \\
\hline $\begin{array}{l}\text { Oct } \\
2011\end{array}$ & $\begin{array}{l}\text { Juliane Kindt, } \\
\text { Gerald Jurasin- } \\
\text { sky }\end{array}$ & Uni Rostock, DE & BSc & Vegetation on limestone & 3,740 & - \\
\hline $\begin{array}{l}\text { Nov } \\
2011\end{array}$ & $\begin{array}{l}\text { Suzanne Rot- } \\
\text { their, Karlè } \\
\text { Sykora }\end{array}$ & Wageningen Univ., NL & $\mathrm{PhD}$ & Dry riverine levee grasslands & 516 & - \\
\hline
\end{tabular}

\section{Outlook}

The future of VegMV depends on funding on the one hand and data quality requirements on the other. At least parts of the database are intended to be included in the freely accessible national vegetation database of Germany (VegetWeb, GIVDID EU-DE-013; see Ewald et al. 2012), and the floristic content will be made available in GBIF, the Global Biodiversity Information Facility (http://www. gbif.org), through the Flora-MV portal (see above).

\section{Acknowledgements}

Data entry was supported by the Job Center of the Federal Republic of Germany and the Ministry of the Environment Mecklenburg-Vorpommern. We thank all scientists involved in the classification of the vegetation of MecklenburgVorpommern: Anja Abdank, Christian Blümel ( $\dagger)$, Bärbel Bohnacker, Ute Clausnitzer, Maike Isermann, Margit Kießlich, Matthias Knapp, Ingo Koska, Christoph Linke, Michael Manthey, Jens Päzolt, Tom Polte, Katrin Runze, Almut Spangenberg, Tiemo Timmermann and Heinrich Wollert.

\section{References}

Archaux, F. (2009): Could we obtain better estimates of plot species richness from multiple-observer plant censuses? Journal of Vegetation Science 20: 603611. CrossRef

Austin, M. (2007): Species distribution models and ecological theory: a critical assessment and some possible new approaches. - Ecological Modelling 200: 1-19. CrossRef

Berg, C. (1993): Bibliographie vegetationskundlicher Literatur in Mecklenburg-Vorpommern (Bundesrepublik Deutschland) bis 1993. - Botanischer Rundbrief Mecklenburg-Vorpommern 25: 5-34.

Berg, C., Dengler, J., Abdank, A. (2001a): Die Pflanzengesellschaften Mecklenburg 
Vorpommerns und ihre Gefährdung Tabellenband. - Jena: Weissdorn

Berg, C., Timmermann, T., Dengler, J. (2001b): Methodische Ansätze für eine "Rote Liste der Pflanzengesellschaften Mecklenburg-Vorpommerns": Naturschutzfachliche Wertstufe. - Berichte der Reinhold-Tüxen-Gesellschaft 13: 217-221.

Berg, C., Dengler, J., Abdank, A., Isermann, M. (2004): Die Pflanzengesellschaften Mecklenburg Vorpommerns und ihre Gefährdung - Textband. - Jena: Weissdorn.

Berg, C., Dengler, J. (2004): Von der Datenbank zur Regionalmonografie - Erfahrungen aus dem Projekt "Die Pflanzengesellschaften MecklenburgVorpommerns und ihre Gefährdung." Berichte der Reinhold-TüxenGesellschaft 16: 29-56.

Berg, C., Dengler, J. (2005): Moose und Flechten als diagnostische Arten von Pflanzengesellschaften - eine Übersicht aus Mecklenburg-Vorpommern. Herzogia 18: 145-161.

Bossard, M., Feranec, J., Otahel, J. (2000): CORINE land cover technical guide: Addendum 2000. - Copenhagen: European Environment Agency.

Cavender-Bares, J., Kozak, K.H., Fine, P.V.A., Kembel, S.W. (2009): The merging of community ecology and phylogenetic biology. - Ecology Letters 12: 693715. CrossRef

Chytrý, M. (2009) [Ed.]: Vegetation of the Czech Republic - 2. Ruderal, weed, rock and scree vegetation [in Czech, with English summary]. - Praha: Academia.

Chytrý, M., Michalcová, D. (2012): Czech National Phytosociological Database. In: Dengler, J., Oldeland, J., Jansen, F., Chytrý, M., Ewald, J., Finckh, M., Glöckler, F., Lopez-Gonzalez, G., Peet, R.K., Schaminée, J.H.J. [Eds.]: Vegetation databases for the 21st century. - Biodiversity \& Ecology 4: 345-345. Hamburg: Biocentre Klein Flottbek and Botanical Garden. CrossRef

Chytrý, M., Rafajová, M. (2003): Czech National Phytosociological Database: basic statistics of the available vegetation-plot data. - Preslia 75: 1-15.

Chytrý, M., Hejcman, M., Hennekens, S.M., Schellberg, J. (2009a): Changes in vegetation types and Ellenberg indicator values after 65 years of fertilizer application in the Rengen Grassland Experiment, Germany. - Applied Vegetation Science 12: 167-176.

Chytrý, M., Pyšek, P., Wild, J., Pino, J., Maskell, L.C., Vilà, M. (2009b): European map of alien plant invasions based on the quantitative assessment across habitats. - Diversity and Distributions 15: 98-107.

Cingolani, A.M., Cabido, M., Gurvich, D.E., Renison, D., Díaz, S. (2007): Filtering processes in the assembly of plant communities: Are species presence and abundance driven by the same traits? Journal of Vegetation Science 18: 911920. CrossRef

Dengler, J., Allers, M.-A. (2006): Plant species richness of the central European landscape on different spatial scales measured with a new approach. Poster at the 36th Annual Conference of the GfÖ, 11.-14.09.06, Bremen (Germany). - URL: http://www.biologie.unihamburg.de/bzf/ fbha063/JD-P16.pd [accessed 7 November 2011]

Dengler, J., Berg, C., Jansen, F. (2005): New ideas for modern phytosociological monographs. - Annali di Botanica Nuova Serie 5: 193-210.

Dengler, J., Rūsina, S., Boch, S., Bruun, H. H., Diekmann, M., Dierßen, K., Dolnik, C., Dupré, C., Golub, V. B., Grytnes, J. A., Helm, A., Ingerpuu, N., Löbel, S., Pärtel, M., Rašomavičius, V., Tyler, G., Znamenskiy, S. R., Zobel, M. (2006): Working group on dry grasslands in the Nordic and Baltic region - Outline of the project and first results for the class Festuco-Brometea. - Annali di Botanica Nuova Serie. 6: 1-28.

Dengler, J., Chytrý, M., Ewald, J. (2008) Phytosociology. - In Jørgensen, S.E., Fath, B.D. [Eds.]: Encyclopedia of ecology: 2767-2779. Oxford: Elsevier.

Dengler, J., Jansen, F., Glöckler, F., Peet, R.K., De Cáceres, M., Chytrý, M., Ewald, J., Oldeland, J., Finckh, M., Lopez-Gonzalez, G., Mucina, L., Rodwell, J.S., Schaminée, J.H.J., Spencer, N. (2011): The Global Index of VegetationPlot Databases (GIVD): a new resource for vegetation science. - Journal of Vegetation Science 22: 582-597. CrossRef

Ewald, J. (2001): Der Beitrag pflanzensoziologischer Datenbanken zur vegetationsökologischen Forschung. - Berichte der Reinhold-Tüxen-Gesellschaft 13 53-69.

Ewald, J. (2002): A probabilistic approach to estimating species pools from large compositional matrices. - Journal of Vegetation Science 13: 191-198. CrossRef

Ewald, J. (2003): A critique for phytosociology. - Journal of Vegetation Science 14: 291-296. CrossRef

Ewald, J., May, R., Kleikamp, M. (2012) VegetWeb - the national onlinerepository of vegetation plots from Germany. - In: Dengler, J., Oldeland, J., Jansen, F., Chytrý, M., Ewald, J., Finckh, M., Glöckler, F., LopezGonzalez, G., Peet, R.K., Schaminée, J.H.J. [Eds.]: Vegetation databases for the 21st century. - Biodiversity \& Ecology 4: 173-175. Hamburg: Biocentre Klein Flottbek and Botanical Garden. CrossRef

Fischer, P., Heinken, T., Meyer, P., Schmidt, M., Waesch, G. (2009): Zur Abgrenzung und Situation des $\mathrm{FFH}$ -
Lebensraumtyps "Mitteleuropäische Flechten-Kiefernwälder" (91TO) in Deutschland. - Natur und Landschaft 84: 281-287.

Fridley, J.D., Vandermast, D.B., Kuppinger, D.M., Manthey, M., Peet, R.K. (2007): Co-occurrence based assessment of habitat generalists and specialists: a new approach for the measurement of niche width. - Journal of Ecology 95: 707-722. CrossRef

Gosch, R., Berg, C. (2011): Ricciocarpos natans (Bryophyta, Ricciaceae) neu für die Steiermark mit Anmerkungen zum Riccietum fluitantis. - Mitteilungen des Naturwissenschaftlichen Vereines für Steiermark 141: 81-92.

Gotelli, N.J., McCabe, D.J. (2002): Species co-occurrence: a meta-analysis of J.M. Diamond's assembly rules model. Ecology 83: 2091-2096. CrossRef

Hennekens, S.M., Schaminée, J.H.J. (2001): TURBOVEG, a comprehensive data base management system for vegetation data. - Journal of Vegetation Science 12: 589-591. CrossRef

Isermann, M. (2008) Classification and habitat characteristics of plant communities invaded by the non-native Rosa rugosa Thunb. in NW Europe. - Phytocoenologia 38: 133-150. CrossRef

Jandt, U., Bruelheide, H. (2012): GVRD German Vegetation Reference Database. - In: Dengler, J., Oldeland, J., Jansen, F., Chytrý, M., Ewald, J., Finckh, M., Glöckler, F., LopezGonzalez, G., Peet, R.K., Schaminée, J.H.J. [Eds.]: Vegetation databases for the 21st century. - Biodiversity \& Ecology 4: 355-355. Hamburg: Biocentre Klein Flottbek and Botanical Garden. CrossRef

Jansen, F., Dengler, J. (2008): GermanSL - eine universelle taxonomische Referenzliste für Vegetationsdatenbanken. Tuexenia 28: 239-253.

Jansen, F., Dengler, J. (2010): Plant names in vegetation databases - a neglected source of bias. - Journal of Vegetation Science 21: 1179-1186. CrossRef

Jansen, F., Ewald, J., Zerbe, S. (2011a): Ecological preferences of alien plant species in North-Eastern Germany. Biological Invasions 13: 2691-2707 CrossRef

Jansen, F., Dengler, J., Glöckler, F., Chytrý, M., Ewald, J., Oldeland, J., Schaminée, J.H.J. (2011b): Die mitteleuropäischen Datenbanken im Global Index of vegetation-plot databases (GIVD). - Tuexenia 31: 351-366.

Jansen, L.J.M., Gregorio, A.D. (2002): Parametric land cover and land-use classifications as tools for environmental change detection. - Agriculture, Ecosystems and Environment 91: 89-100. CrossRef

Lemke, T. (2007). Botanische Kostbarkeiten in Deutschland: die Trollblume 
(Trollius europaeus L., Ranunculaceae). - Pulsatilla 9: 13-17.

Lenoir, J., Gégout, J.-C., Guisan, A., Vittoz, P., Wohlgemuth, T., Zimmermann, N.E., Dullinger, S., Pauli, H., Willner, W., Grytnes, J.-A., Virtanen, R., Svenning, J.-C. (2010). Cross-scale analysis of the region effect on vascular plant species diversity in southern and northern European mountain ranges. PLoS One 5: Article e15734.

Libbert, W. (1933): Die Vegetationseinheiten der neumärkischen Staubeckenlandschaft unter Berücksichtigung der angrenzenden Landschaften. 2. Teil. Verhandlungen des Botanischen Vereins der Provinz Brandenburg 75: 229348.

Litterski, B., Abdank, A., Wiehle, W., Berg, C. (1997): Zusammenstellung geobotanischer Diplomarbeiten, Gutachten und Forschungsberichte aus dem Gebiet Mecklenburg-Vorpommern der Jahre 1991-1995. - Botanischer Rundbrief Mecklenburg-Vorpommern 30: 133-156.

Michalcová, D., Lvončík, S., Chytrý, M., Hájek, O. (2011): Bias in vegetation databases? A comparison of stratifiedrandom and preferential sampling. Journal of Vegetation Science 22: 281291.
Mucina, L., Schaminée, J.H.J., Rodwell, J.S. (2000): Common data standards for recording relevés in field survey for vegetation classification. - Journal of Vegetation Science 11: 769-772. CrossRef

Schaminée, J.H.J., Hennekens, S.M., Chytrý, M., Rodwell, J.S. (2009): Vegetation-plot data and databases in Europe: an overview. - Preslia 81: 173185.

Schulze, G., Kopp, D. (2006): Anleitung für die forstliche Standortserkundung in den Wäldern des Landes MecklenburgVorpommern: SEA 95. - Schwerin: Ministerium für Landwirtschaft und Naturschutz Mecklenburg-Vorpommern [Loose-leaf-collection].

Timmermann, T., Dengler, J., Abdank, A., Berg, C. (2006): Objektivierung von $\mathrm{Na}-$ turschutzbewertungen. Das Beispiel Roter Listen von Pflanzengesellschaften. Naturschutz und Landschaftsplanung 38: 133-139.

Vittoz, P., Guisan, A. (2007): How reliable is the monitoring of permanent vegetation plots? A test with multiple observers. - Journal of Vegetation Science 18: 413-422. CrossRef

Wisskirchen, R., Haeupler, H. (1998): Standardliste der Farn- und Blütenpflanzen Deutschlands. - Stuttgart: Ulmer.
Florian Jansen* (jansen@unigreifswald.de)

Landscape Ecology and Ecosystem Dynamics (LEED), Institute of Botany and Landscape Ecology, University of Greifswald

Grimmer Str. 88

17487 Greifswald, GERMANY

Jürgen Dengler (dengler@botanik.unihamburg.de)

Biodiversity, Evolution and Ecology of Plants (BEE), Biocentre Klein Flottbek and Botanical Garden, University of

Hamburg

Ohnhorststr. 18

22609 Hamburg, GERMANY

Christian Berg (christian.berg@unigraz.at)

Systematic Botany and Botanical Garden, Department of Plant Sciences, University of Graz

Holteigasse 6

8010 Graz, AUSTRIA

*Corresponding author 